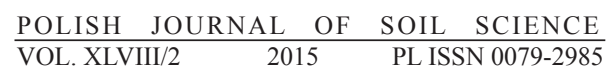

DOI: $10.17951 / \mathrm{pjss} / 2015.48 .2 .131$

Soil Physics

\author{
BARBARA KALISZ*, ANDRZEJ ŁACHACZ*, ANDRZEJ KLASA** \\ SŁAWOMIR SMÓLCZYŃSKI*, MIROSŁAW ORZECHOWSKI* \\ PAWEŁ SOWIŃSKI*
}

\title{
WATER PERMEABILITY OF SOILS AMENDED WITH SEWAGE SLUDGE ON SHORT-ROTATION PLANTATIONS IN EUROPE
}

Abstract. Soil permeability is the measure of the soil's ability to permit water to flow through soil pores. It depends chiefly on the volume and geometry of soil pores, bulk density, and soil structure. Studied soils were overgrown with short-rotation plantations of Salix and amended with sewage sludge in Germany, Estonia, and Poland. Sewage sludge application as well as the use of soils influenced water permeability.

Soil permeability or hydraulic conductivity is the measure of the soil's ability to permit water to flow through soil pores. It depends on the volume and geometry of soil pores, bulk density, and soil structure [3]. Soil water permeability is determined on the basis of $\mathrm{K}$ coefficient, which was characterised in Darcy's equation for the discharge velocity of soil water flowing through saturated soil: $\mathrm{v}=\mathrm{K} * \mathrm{I}$, where $\mathrm{v}$ is the discharge velocity, i.e. the quantity of water flowing in a unit of time through a unit of gross cross-sectional area of soil at right angles to the direction of flow, and $\mathrm{K}$ is the hydraulic conductivity (coefficient of permeability), and I is the decrease in hydraulic pressure calculated

* B. Kalisz, DSc., Prof. A. Łachacz, DSc., Assoc. Prof. S. Smólczyński, DSc., Assoc. Prof. M. Orzechowski, DSc.; Department of Soil Science and Land Reclamation, Faculty of Environmental Management and Agriculture, University of Warmia and Mazury in Olsztyn, Plac Łódzki 3, 10-727 Olsztyn, Poland;

** A. Klasa, DSc.; Department of Agricultural Chemistry and Environmental Protection, Faculty of Environmental Management and Agriculture, University of Warmia and Mazury in Olsztyn, ul. Oczapowskiego 8, 10-744 Olsztyn, Poland. 
on the basis of pressure and length of flow. The coefficient of permeability may be mathematically predicted, measured in field conditions or at a laboratory in saturated and unsaturated soils $[1,3,9]$.

Soil water permeability affects the availability of water for plants and determines the flow of nutrients in soils [10]. According to Walczak et al. [11] recognition of hydrophysical properties is necessary to interpret and predict most processes occurring in the soil. Measurements of soil saturated hydraulic conductivity and their spatial variations are important to characterise hydrological processes in the field scale [2].

The aim of the study has been to determine whether application of sewage sludge influences the water permeability of soil.

\section{MATERIALS AND METHODS}

Studied soils were overgrown with short-rotation plantations of Salix and amended with sewage sludge in Germany, Estonia, and Poland. In Germany the experimental field was located in Schönberg-Holstein in the north of Germany, 3 $\mathrm{km}$ away from the Baltic Sea and $20 \mathrm{~km}$ away from the City of Kiel (geographical coordinates: $\left.54^{\circ} 23^{\prime} 50.55^{\prime \prime} 0 \mathrm{~N}, 10^{\circ} 23^{\prime} 05.89^{\prime \prime} 5 \mathrm{E}\right)$. The annual average precipitation rate in this region was $825 \mathrm{~mm}$ with the annual average temperature of $10.8{ }^{\circ} \mathrm{C}$. In Estonia the experimental field was situated in the Tartu Region, Vara Borough, with the coordinates of 58 $30^{\prime} 18^{\prime \prime} 8 \mathrm{~N}, 26^{\circ} 55^{\prime} 29^{\prime \prime} 9 \mathrm{E}$. The annual average precipitation in this region was $620 \mathrm{~mm}$, and the average temperature was $5.2{ }^{\circ} \mathrm{C}$. In Poland the field was located in Lisiecice, in the Opole Region,

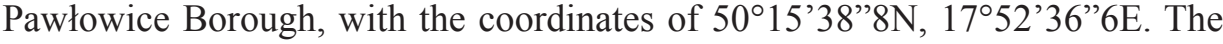
annual average precipitation in the region was $650 \mathrm{~mm}$, and the annual temperature was $8.2^{\circ} \mathrm{C}$.

The experimental field was a randomised block design, and each sludge treatment was repeated five times. Each block consisted of three sludge treatment processes for one willow clone.

According to the World Reference Base for Soil Resources [12], Polish and German studied soils were classified as Cambisols. They contain less than 2.5\% of organic carbon (OC) in topsoil and do not meet the requirements of mollic horizon. Their sub-surface horizon is cambic and their texture is loamy. Estonian soils were classified as Phaeozems. They have topsoil rich in organic matter which contains more than $2.5 \%$ of OC. Organic matter content, colour and $\mathrm{pH}$ enable to classify it as mollic diagnostic horizon. Their texture is sandy loam.

The sewage sludge applied on the studied soils contained considerable amounts of organic matter and nutrients (Table 1). Sewage sludge was stabilised with lime, which is a normal practice at sewage treatment plants [4]. Sewage sludge was applied once in two rates calculated on the basis of phosphorus content. Sewage sludge was incorporated and thoroughly mixed by disc harrows 
two weeks before willow planting. The single rate (sewage sludge single rate -SSs) contained $60 \mathrm{~kg}$ P per hectare and the double one (sewage sludge double rate -SSd) contained $120 \mathrm{~kg}$ P per hectare. The amount of organic matter introduced with sewage sludge with the single rate and double rate were as follows: in Estonia 1.59 and $3.18 \mathrm{t}$ per hectare, in Germany 0.99 and $1.98 \mathrm{t}$ per hectare, in Poland 1.97 and 3.94 t per hectare, respectively.

TABLE 1. GENERAL PROPERTIES OF THE SEWAGE SLUDGE APPLIED

\begin{tabular}{|c|c|c|c|}
\hline Parameter & ESTONIA & GERMANY & POLAND \\
\hline Dry matter $[\%]$ & 29.79 & 23.30 & 43.96 \\
\hline $\begin{array}{c}\text { Organic matter }[\% \\
\text { DM] }\end{array}$ & 52.94 & 46.58 & 43.67 \\
\hline $\mathrm{pH}$ & 7.88 & n.d. ${ }^{\text {a) }}$ & 11.05 \\
\hline \multicolumn{4}{|c|}{ Total content of macronutrients $\left[\mathrm{g} \mathrm{kg}^{-1} \mathrm{DM}\right]$} \\
\hline $\mathrm{N}$ & 22.7 & 23.1 & 27.5 \\
\hline $\mathrm{P}$ & 20.0 & 28.2 & 13.3 \\
\hline $\mathrm{K}$ & 3.0 & n.d. & n.d. \\
\hline $\mathrm{Ca}$ & 55.0 & n.d. & 78.8 \\
\hline $\mathrm{Mg}$ & 7.2 & n.d. & 8.8 \\
\hline
\end{tabular}

a) n.d. - not determined.

Soil bulk density (BD) and soil moisture content were determined in 100 $\mathrm{cm}^{3}$ of an undisturbed core sample after drying to constant weight at $105^{\circ} \mathrm{C}$. Soil specific density (SD) was measured by means of pycnometers. Soil total porosity (TP) was calculated, using the following equation (Kutílek and Nielsen 1994):

$$
\mathrm{TP}=\frac{(\mathrm{SD}-\mathrm{BD})}{\mathrm{SD}} \times 100 \quad[\%, \mathrm{v} / \mathrm{v}]
$$

The porosity index was calculated according to the equation: porosity index $=\mathrm{TP} /(100-\mathrm{TP})$, where $\mathrm{TP}$ is total porosity.

Water permeability was determined in undisturbed soil samples taken to stainless steel sample rings $\left(250 \mathrm{~cm}^{3}\right)$. Soil samples were saturated in a water tank for 1-2 weeks and then placed in the laboratory permeameter. For the purpose of this study a permeameter type Eheim 1048 produced by the Eijkelkamp Agrisearch Equipment was used. Every sample was analysed in minimum ten replications. First the water flow in a unit of time (Q) was determined, then the coefficient $\mathrm{K}_{\mathrm{t}}$, at a laboratory temperature, and $\mathrm{K}_{10}$, the coefficient of permeability at $10{ }^{\circ} \mathrm{C}$ were calculated. 
For the purpose of the texture analysis, the pipette method, using the apparatus produced by Eijkelkamp Agrisearch Equipment (the International Standard -ISO 13317-2:2001) was applied. Soil material of $ø<2 \mathrm{~mm}$ was used after sample pre-treatment, i.e. organic matter removal by oxidation with $30 \% \mathrm{H}_{2} \mathrm{O}_{2}$ and removal of calcium carbonates by $\mathrm{HCl}$ solutions. Soil texture classes were given in accordance with the Polish classification of the Polish Society of Soil Science [8].

\section{RESULTS AND DISCUSSION}

Estonian and German soils had sandy loam, and Polish soils had silt loam texture (Table 2). The highest content of clay fraction was found in Polish soils $(19.26 \%)$ and the lowestone - in Estonian soils. The highest content of silt fraction was recorded in Polish soils (66.73\%), twice lower content was found in Estonian ones $(29.15 \%)$ and the lowest - in German ones (21.77\%). Contrary to the silt content, German soils contained the highest amount (62.03\%) and Polish soils the lowest amount (14.02\%) of sand. Differences in grain-size-distribution within soils taken from various plots of the field trails were small. Taking into consideration the size of an individual plot $\left(20 \mathrm{~m}^{2}\right)$, the differences in granulometric composition could be attributed to natural soil variability. In other words, the application of sewage sludge in the doses introduced did not change granulometric composition of the soils studied. However, prolonged application of sewage sludge could enhance the content of fine clay particles, as this organic fertiliser contains not only organic matter but also substantial amounts of colloidal mineral particles.

\section{TABLE 2. TEXTURE OF STUDIED SOILS}

\begin{tabular}{|c|c|c|c|c|c|c|c|}
\hline & \multirow{2}{*}{ Plot } & \multicolumn{5}{|c|}{ Percentage of particles ( $\varnothing$ in mm) } & \multirow{2}{*}{$\begin{array}{l}\text { Soil } \\
\text { texture }\end{array}$} \\
\hline & & $>2.0$ & $2.0-0.05$ & $0.05-0.02$ & $0.02-0.002$ & $<0.002$ & \\
\hline $\begin{array}{l}\text { MN } \\
\text { (SD) }\end{array}$ & $\begin{array}{l}\text { Estonia } \\
\text { Control }\end{array}$ & $\begin{array}{c}3.99 \\
(1.14)\end{array}$ & $\begin{array}{l}58.53 \\
(2.53)\end{array}$ & $\begin{array}{l}10.93 \\
(1.87)\end{array}$ & $\begin{array}{l}16.41 \\
(2.55)\end{array}$ & $\begin{array}{l}14.13 \\
(1.26)\end{array}$ & $\begin{array}{l}\text { sandy } \\
\text { loam }\end{array}$ \\
\hline $\begin{array}{l}\mathrm{MN} \\
\text { (SD) }\end{array}$ & $\begin{array}{c}\text { Estonia } \\
\text { SSs }\end{array}$ & $\begin{array}{c}4.42 \\
(0.65)\end{array}$ & $\begin{array}{l}57.14 \\
(4.65)\end{array}$ & $\begin{array}{l}11.93 \\
(3.24)\end{array}$ & $\begin{array}{l}16.97 \\
(3.27)\end{array}$ & $\begin{array}{l}13.96 \\
(1.57)\end{array}$ & $\begin{array}{l}\text { sandy } \\
\text { loam }\end{array}$ \\
\hline $\begin{array}{l}\mathrm{MN} \\
\text { (SD) }\end{array}$ & $\begin{array}{c}\text { Estonia } \\
\text { SSd }\end{array}$ & $\begin{array}{c}4.86 \\
(0.28)\end{array}$ & $\begin{array}{l}53.51 \\
(6.60)\end{array}$ & $\begin{array}{l}14.00 \\
(5.28)\end{array}$ & $\begin{array}{l}17.20 \\
(1.97)\end{array}$ & $\begin{array}{l}15.29 \\
(3.68)\end{array}$ & $\begin{array}{l}\text { sandy } \\
\text { loam }\end{array}$ \\
\hline $\begin{array}{l}\text { MN } \\
\text { (SD) }\end{array}$ & $\begin{array}{c}\text { Germany } \\
\text { Control }\end{array}$ & $\begin{array}{c}9.98 \\
(3.73)\end{array}$ & $\begin{array}{l}60.75 \\
(3.24)\end{array}$ & $\begin{array}{c}7.16 \\
(0.88)\end{array}$ & $\begin{array}{l}15.13 \\
(2.13)\end{array}$ & $\begin{array}{l}16.96 \\
(1.77)\end{array}$ & $\begin{array}{l}\text { sandy } \\
\text { loam }\end{array}$ \\
\hline $\begin{array}{l}\text { MN } \\
\text { (SD) }\end{array}$ & $\begin{array}{c}\text { Germany } \\
\text { SSs }\end{array}$ & $\begin{array}{c}8.69 \\
(2.02)\end{array}$ & $\begin{array}{l}63.53 \\
(4.16)\end{array}$ & $\begin{array}{c}7.67 \\
(2.21)\end{array}$ & $\begin{array}{l}13.81 \\
(1.53)\end{array}$ & $\begin{array}{l}15.00 \\
(2.20)\end{array}$ & $\begin{array}{l}\text { sandy } \\
\text { loam }\end{array}$ \\
\hline $\begin{array}{l}\mathrm{MN} \\
\text { (SD) }\end{array}$ & $\begin{array}{c}\text { Germany } \\
\text { SSd }\end{array}$ & $\begin{array}{c}9.18 \\
(2.54)\end{array}$ & $\begin{array}{l}61.82 \\
(2.87)\end{array}$ & $\begin{array}{c}7.34 \\
(1.23) \\
\end{array}$ & $\begin{array}{l}14.19 \\
(0.81) \\
\end{array}$ & $\begin{array}{l}16.65 \\
(2.32) \\
\end{array}$ & $\begin{array}{l}\text { sandy } \\
\text { loam }\end{array}$ \\
\hline $\begin{array}{l}\mathrm{MN} \\
\text { (SD) }\end{array}$ & $\begin{array}{l}\text { Poland } \\
\text { Control }\end{array}$ & $\begin{array}{c}0.96 \\
(0.60)\end{array}$ & $\begin{array}{l}13.65 \\
(1.66)\end{array}$ & $\begin{array}{l}34.81 \\
(2.64)\end{array}$ & $\begin{array}{l}31.85 \\
(2.39)\end{array}$ & $\begin{array}{l}19.69 \\
(2.29)\end{array}$ & $\begin{array}{c}\text { silt } \\
\text { loam }\end{array}$ \\
\hline $\begin{array}{l}\mathrm{MN} \\
(\mathrm{SD})\end{array}$ & $\begin{array}{c}\text { Poland } \\
\text { SSs }\end{array}$ & $\begin{array}{c}1.23 \\
(0.39) \\
\end{array}$ & $\begin{array}{l}15.05 \\
(2.30) \\
\end{array}$ & $\begin{array}{l}33.25 \\
(2.95)\end{array}$ & $\begin{array}{l}34.73 \\
(2.32) \\
\end{array}$ & $\begin{array}{l}16.97 \\
(1.90) \\
\end{array}$ & $\begin{array}{c}\text { silt } \\
\text { loam }\end{array}$ \\
\hline $\begin{array}{l}\mathrm{MN} \\
\text { (SD) }\end{array}$ & $\begin{array}{l}\text { Poland } \\
\text { SSd }\end{array}$ & $\begin{array}{c}1.31 \\
(0.13)\end{array}$ & $\begin{array}{l}13.35 \\
(2.32)\end{array}$ & $\begin{array}{l}32.73 \\
(1.09)\end{array}$ & $\begin{array}{l}32.80 \\
(2.08)\end{array}$ & $\begin{array}{l}21.13 \\
(3.86)\end{array}$ & $\begin{array}{c}\text { silt } \\
\text { loam }\end{array}$ \\
\hline
\end{tabular}

$\mathrm{MN}$ - mean; SD - standard deviation. 
In Estonian test-field soils, sewage sludge application did not contribute to distinct changes in soil bulk density (BD) and soil specific density (Table 3). The analysed soils were appropriately compacted for agricultural use (BD $\left.1.2 \mathrm{~g} \mathrm{~cm}^{-3}\right)$. Soil total porosity (TP) amounted to $53 \%$ in the plots without any treatment. After sewage sludge application, a small decrease in soil total porosity was observed (Table 3). In German soils, soil bulk density and soil total porosity increased after sewage sludge application but without correlation with the rate of sewage sludge applied. The soil porosity index was low and amounted to 0.5 . Taking into consideration the bulk density of those soils, they could be classified as well-compacted. In Polish soils, similarly to Estonian plots, no distinct changes in soil bulk density (BD) and soil specific density were recorded. The analysed soils were compacted (BD $1.4 \mathrm{~g}$ $\left.\mathrm{cm}^{-3}\right)$. Soil total porosity (TP) amounted to $41.7 \%$ in the plots without sewage sludge treatment and increased after sewage sludge application up to $43.32 \%$ in the plots where the double rate of sewage sludge had been applied (Table 3). Sewage sludge application modified total porosity, bulk density, and solid density of the test field soils. However, the changes were minor because the rates of SS were small. Statistical analysis for soil bulk density and soil total porosity did not show significant differences between control plots and plots fertilised with sewage sludge. Similar results were obtained by Łachacz et al. [5]. In order to significantly change soil bulk density and total porosity, higher rates of sewage sludge would have to be applied.

TABLE 3. PHYSICAL PROPERTIES OF STUDIED SOILS

\begin{tabular}{|l|c|c|c|c|c|c|}
\hline Plot & $\begin{array}{c}\text { Bulk density } \\
\text { of dry soil } \\
{\left[\mathrm{g} \mathrm{cm}^{-3}\right]}\end{array}$ & $\begin{array}{c}\text { Bulk density } \\
\text { of moist soil } \\
{\left[\mathrm{g} \mathrm{cm}^{-3}\right]}\end{array}$ & $\begin{array}{c}\text { Specific } \\
\text { density } \\
{\left[\mathrm{g} \mathrm{cm}^{-3}\right]}\end{array}$ & $\begin{array}{c}\text { Total poro- } \\
\text { sity } \\
{[\%]}\end{array}$ & $\begin{array}{c}\text { Porosity } \\
\text { index* }\end{array}$ \\
\hline MN & Estonia & 1.235 & 1.537 & 2.600 & 53.19 & 1.106 \\
SD) & Control & $(0.034)$ & $(0.045)$ & $(0.031)$ & $(2.41)$ & $(0.053)$ \\
\hline MN & Estonia & 1.243 & 1.578 & 2.608 & 52.34 & 1.099 \\
(SD) & SSs & $(0.036)$ & $(0.040)$ & $(0.041)$ & $(1.18)$ & $(0.052)$ \\
\hline MN & Estonia & 1.239 & 1.544 & 2.553 & 52.36 & 1.061 \\
(SD) & SSd & $(0.041)$ & $(0.013)$ & $(0.072)$ & $(0.96)$ & $(0.067)$ \\
\hline MN & Germany & 1.643 & 1.960 & 2.560 & 35.84 & 0.560 \\
(SD) & Control & $(0.070)$ & $(0.069)$ & $(0.038)$ & $(2.46)$ & $(0.059)$ \\
\hline MN & Germany & 1.681 & 2.005 & 2.534 & 33.65 & 0.509 \\
(SD) & SSs & $(0.045)$ & $(0.034)$ & $(0.055)$ & $(2.82)$ & $(0.065)$ \\
\hline MN & Germany & 1.668 & 1.986 & 2.558 & 34.76 & 0.534 \\
$(\mathrm{SD})$ & SSd & $(0.025)$ & $(0.025)$ & $(0.052)$ & $(2.02)$ & $(0.046)$ \\
\hline MN & Poland & 1.452 & 1.655 & 2.493 & 41.70 & 0.717 \\
$(\mathrm{SD})$ & Control & $(0.030)$ & $(0.053)$ & $(0.106)$ & $(1.77)$ & $(0.052)$ \\
\hline MN & Poland & 1.415 & 1.616 & 2.483 & 42.93 & 0.758 \\
(SD) & SSs & $(0.067)$ & $(0.095)$ & $(0.075)$ & $(3.79)$ & $(0.120)$ \\
\hline MN & Poland & 1.429 & 1.633 & 2.521 & 43.32 & 0.766 \\
(SD) & SSd & $(0.055)$ & $(0.069)$ & $(0.079)$ & $(2.15)$ & $(0.070)$ \\
\hline
\end{tabular}

* Porosity index $=$ total porosity/(100-total porosity). 
The water permeability coefficient $\left(\mathrm{K}_{10}\right)$ of Estonian soils varied greatly among plots and amounted from $0.834 \mathrm{~m} \mathrm{~d}^{-1}$ to $116.072 \mathrm{~m} \mathrm{~d}^{-1}$ (Table 4). Sewage sludge application increased water permeability of the soils studied. Water permeability of soil at Polish willow plots, similarly to Estonian ones, varied (Table 4). Many soils had low permeability coefficient $\left(\mathrm{K}_{10}\right)$ - below $1.0 \mathrm{~m} \mathrm{~d}^{-1}$. Water permeability of the analysed German soils was generally low (Table 4). The water permeability coefficient showed the highest values in Estonian soils, which is connected with soil bulk density and total porosity. Bulk density of those soils was the lowest and total porosity was the highest among investigated soils. The lowest permeability was recorded in German soils and their bulk density was the highest.

TABLE 4. WATER PERMEABILITY OF STUDIED SOILS

\begin{tabular}{|c|c|c|c|c|}
\hline & \multirow{2}{*}{ Plot } & Q & $\mathrm{K}_{\mathrm{t}}$ & $\mathrm{K}_{10}$ \\
\hline & & {$\left[\mathrm{cm}^{3} \mathrm{~min}^{-1}\right]$} & {$\left[\mathrm{m} \mathrm{d}^{-1}\right]$} & {$\left[\mathrm{m} \mathrm{d}^{-1}\right]$} \\
\hline $\mathrm{MN}$ & \multirow{3}{*}{$\begin{array}{l}\text { Estonia } \\
\text { Control }\end{array}$} & 2.476 & 18.190 & 22.023 \\
\hline SD & & 1.974 & 10.392 & 12.598 \\
\hline $\mathrm{ME}$ & & 2.593 & 16.978 & 20.543 \\
\hline $\mathrm{MN}$ & \multirow{3}{*}{$\begin{array}{c}\text { Estonia } \\
\text { SSs }\end{array}$} & 2.728 & 18.624 & 22.576 \\
\hline SD & & 3.613 & 17.916 & 21.638 \\
\hline $\mathrm{ME}$ & & 1.310 & 17.822 & 21.647 \\
\hline $\mathrm{MN}$ & \multirow{3}{*}{$\begin{array}{c}\text { Estonia } \\
\text { SSd }\end{array}$} & 4.037 & 20.993 & 25.491 \\
\hline SD & & 3.850 & 31.839 & 38.490 \\
\hline $\mathrm{ME}$ & & 3.003 & 9.458 & 11.599 \\
\hline $\mathrm{MN}$ & \multirow{3}{*}{$\begin{array}{c}\text { Germany } \\
\text { Control }\end{array}$} & 0.086 & 0.365 & 0.453 \\
\hline SD & & 0.153 & 0.775 & 0.961 \\
\hline $\mathrm{ME}$ & & 0.032 & 0.026 & 0.033 \\
\hline $\mathrm{MN}$ & \multirow{3}{*}{$\begin{array}{c}\text { Germany } \\
\text { SSs }\end{array}$} & 0.117 & 0.386 & 0.481 \\
\hline SD & & 0.139 & 0.763 & 0.946 \\
\hline ME & & 0.074 & 0.061 & 0.078 \\
\hline $\mathrm{MN}$ & \multirow{3}{*}{$\begin{array}{l}\text { Germany } \\
\text { SSd }\end{array}$} & 0.031 & 0.042 & 0.054 \\
\hline SD & & 0.053 & 0.070 & 0.089 \\
\hline $\mathrm{ME}$ & & 0.008 & 0.016 & 0.021 \\
\hline $\mathrm{MN}$ & \multirow{3}{*}{$\begin{array}{l}\text { Poland } \\
\text { Control }\end{array}$} & 2.604 & 4.294 & 5.375 \\
\hline SD & & 4.234 & 7.825 & 9.810 \\
\hline $\mathrm{ME}$ & & 0.585 & 0.729 & 0.905 \\
\hline $\mathrm{MN}$ & \multirow{3}{*}{$\begin{array}{c}\text { Poland } \\
\text { SSs }\end{array}$} & 0.583 & 0.552 & 0.695 \\
\hline SD & & 0.590 & 0.573 & 0.729 \\
\hline $\mathrm{ME}$ & & 0.516 & 0.443 & 0.551 \\
\hline $\mathrm{MN}$ & \multirow{3}{*}{$\begin{array}{l}\text { Poland } \\
\text { SSd }\end{array}$} & 3.833 & 5.756 & 7.195 \\
\hline SD & & 4.502 & 7.617 & 9.478 \\
\hline $\mathrm{ME}$ & & 1.451 & 1.976 & 2.459 \\
\hline
\end{tabular}

$\mathrm{ME}$ - median; $\mathrm{Q}$ - volume of water flowing through the sample during a period of time; $\mathrm{K}_{\mathrm{t}}$ - permeability coefficient at the applied temperature; $\mathrm{K}_{10}$ - permeability coefficient at $10{ }^{\circ} \mathrm{C}$ (corrected coefficient at $\left.10^{\circ} \mathrm{C}\right)$. 
According to permeability classes for agriculture and conservation elaborated by the FAO [13], Estonian soils have very rapid, moderate, and moderately rapid class of water permeability. German control soils have moderately slow permeability class. The increase in permeability was recorded for soils fertilised with the single rate of SS (moderate permeability) whereas soils fertilised with the double rate of SS had very slow permeability class. In German soils no relation between the rate of SS and permeability was stated. Polish control soils show rapid permeability. However, the differences between the examined soils were considerable $\left(\mathrm{K}_{10}\right.$ was from 0.025 to $\left.27.847 \mathrm{~m} \mathrm{~d}^{-1}\right)$. Contrary to German tested soils, the decrease in water permeability was recorded for Polish soils fertilised with the single rate of SS (moderate permeability) and the increase - for soils fertilised with the double rate of SS (very rapid permeability).

Sewage sludge application as well as the way of land use influenced water permeability. The presence of small stones, earthworms or sprouts in agriculturally used soils influences water permeability. The volume of pores greater than 150 micrometers also increases after application of organic amendments, which has an impact on water permeability in soil $[6,7]$.

\section{REFERENCES}

[1] F r e d l u n d D.G., X ing A., H u a ng S.: Can. Geotech. J., 31, 3, 521,1994.

[2] H u W., S h a o M., W a $\mathrm{g}$ Q., S h e D.: J. Hydrol. Eng., 18, 4, 378, 2013.

[3] I w a n e k M.: Acta Agrophysics, 5, 1, 39, 2005.

[4] K a l is z B., Ła c h a c z A., G ł a że w s ki R., K l a s a A.: Arch. Envir. Prot., 38, 4, 87, 2012.

[5] Ł a ch ac z A., Grabow ski K., K a l is z B., B i edrzyck a A.: Polish J. Environ. Stud., 16, 3B, 299, 2007.

[6] O rt e g a E., N o g a le s R., D e 1 g a d o M.: Agrobiología, 40, 9/10, 1735, 1981.

[7] P a g 1 i a i M., B is d o m E.B.A., L e d in S.: Geoderma, 30, 35, 1983.

[8] PTG.: Soil Science Annuals, 60, 2, 5, 2009.

[9]S a w i c k i E., S tró ż y k J.: Studia Geotechnica et Mechanica, 31, 4, 73, 2009.

[10] Wa 1 c z a k R., O s tr o w s k i J.: Woda-Środowisko-Obszary Wiejskie, 4, 2a, 175, 2004.

[11] Walczak R., Ostrowski J., Witkowska-Walczak B., Sławiński C.: Int. Agrophysics, 16, 151, 2002.

[12] World Reference Base for Soil Resources: World Soil Resources Reports 106, 192, 2015.

[13] World Soil Resources Reports, FAO, 1997.

\section{PRZEPUSZCZALNOŚĆ WODNA GLEB NAWOŻONYCH OSADEM ŚCIEKOWYM NA PLANTACJACH W EUROPIE}

Przepuszczalność wodna gleb charakteryzuje przemieszczanie się wody w profilu glebowym. Zależy przede wszystkim od wielkości i geometrii porów glebowych, gęstości objętościowej i struktury gleby. Badane gleby na plantacjach wierzby nawożone osadem ściekowym w Polsce, Estonii i Niemczech. Zastosowanie osadu ściekowego oraz użytkowanie gleby miało wpływ na przepuszczalność wodną badanych gleb. 